\title{
Mellem neo-patristisk og eusebisk ekklesiologi
}

\author{
Ortodokse ekklesiologiske positioner i den \\ montenegrinske kirkestrid (1993-2013) \\ Cand.theol. \\ Emil Bjørn Hilton Saggau
}

\begin{abstract}
The new European state Montenegro has been a scene for an internal ecclesial strife between the Serbian Orthodox Church and the newly formed Montenegrin Orthodox Church since the early nineties. This article focuses on the ecclesiological models used in the discussion between the two churches. On one side the Montenegrin Church understands itself from the classical juridical "eusebian" church model. This model's main focus is the lawful canonic status of independent churches called autocephaly, which the Montenegrin Church claims to possess. On the other side the Serbian Orthodox Church operates with a Neo-patristic ecclesiological model that claims the Eucharist as the true form for an Orthodox Church. A form that the Serbian Church denies that its Montenegrin counterpart has. The two models are focused on two different key-aspects of the Orthodox ecclesiological complex, which are the canon laws and the genuine patristic tradition.
\end{abstract}

Key words: Orthodox ecclesiology - The Serbian Church - the Montenegrin Church - autocephaly - canon law - patristic tradition - neopatristic theology.

I oktober 2013 drog en forsamling bestående af de åndelige ledere for henholdsvis den serbiske, russiske og jerusalemittiske ortodokse kirke til den montenegrinske hovedstad Podgorica. Her fejrede de ortodokse ledere åbningen af en ny katedral, der cementerede og markerede den serbiske kirkes magt i det lille bjergland Montenegro, der siden 2006 formelt set har været selvstændigt fra Serbien. ${ }^{1}$ Fejringen blev mødt med modstand fra den mindre lokale montenegrinske ortodokse kirke, der ønsker den serbiske kirke ud af landet. De to kirker, henholdsvis den serbiske og den montenegrinske, er på nuværende tidspunkt låst i en langvarig kirkelig konflikt med alvorlige nationale, etniske og politiske implikationer. ${ }^{2}$

1. Se The Serbian Orthodox Church (http://www.spc.rs/eng/podgoricas_church_ consecrated_primates_serve_liturgy, besøgt 05.05.2014)

2. František Sistek, "Clericalization of Nationalisme", Religion and Society: Spaces and Borders: Current Research on Religion in Central and Eastern Europe, red. András 
Denne kirkelige strid er en konflikt, der handler om, hvilken kirke der er den "sande" ortodokse kirke for Montenegros ortodokse befolkning. På den ene side hævder den serbiske kirke, at den er den eneste legitime ortodokse repræsentant for landets "folk", der er serbisk. På den anden side hævder den montenegrinske kirke, at det ortodokse "folk", der er montenegrinsk, har krav på kirkelig selvstændighed. Striden mellem de to kirker i Montenegro er ikke en unik problemstilling i det ortodokse kirkefællesskab, der siden den socialistiske periode har været præget af en række lignede kirkelige konflikter i Makedonien FYROM (Former Yugoslav Republic Of Macedonia), Bulgarien og Ukraine og en række tidligere russiske satellitstater. ${ }^{3}$

Denne artikel vil med udgangspunkt i den verserende montenegrinske kirkestrid belyse, analysere og diskutere de to parters ekklesiologi og deres positioners relation til de ortodokse ekklesiologiske hovedstrømninger. Analysen er begrænset til den ekklesiologiske hoveddiskussion mellem de to kirker, hvorfor en redegørelse for stridens andre aspekter og teologiske diskussioner samt konkrete sammenstød, kampe, kirkebesættelser etc. såvel som de omfattende historiske og nationalistiske aspekter er udeladt.

\section{Montenegros vugge}

Udgangspunktet for striden mellem de to kirker i Montenegro skal først og fremmest findes i den montenegrinske ortodokse kirke, da konflikten udspringer af kirkens formelle (gen-)oprettelse i 1993. Analysen indledes derfor med en udredning og analyse af de promontenegrinske aktørers ekklesiologiske argumenter for kirkelig selvstændighed. I det følgende afsnit vil redegørelsen primært være fokuseret på Goran Sekulovićs tekst "Den montenegrinske identitet - rettigheder og friheder" (serb.: Crnogorska identitetska prava $i$ slobode) udgivet i "Montenegros vugge" (Matica Crnogorska) i 2010. Sekulović repræsenterer de pro-montenegrinske intellektuelle grupper, som har støttet op om den montenegrinske kirke siden begyndel-

Máté-Tóth og Cosima Rughinis (Berlin: De Gruyter 2010), 118- 130.

3. Carsten Riis, En osmannisk arv - historieskrivning og religion i Bulgarien (Aarhus: Aarhus Universitet 1999), 290-293. Den Makedonske Ortodokse Kirke, "A Brief History of the Church Issue in the Republic of Macedonia", (http://www.mpc.org. mk/English/MPC/brief-history.asp, besøgt 05.08.2013). Peter Petkoff, "Churchstate relations under the Bulgarian denominations act 2002", Religion, State and Society 33:4 (2005), 315-337.

4. Alle oversættelser fra serbisk til dansk er egne. 
sen af halvfemserne, og som har gjort sig til de primære talspersoner for kirken. ${ }^{5}$ Sekulović formulerer en ekklesiologisk position for den montenegrinske kirke, som repræsenterer kirkens egen selvopfattelse. ${ }^{6}$

Sekulović fremhæver især to centrale historiske begivenheder i sin tekst. Disse historiske fikspunkter i hans position er opløsningen af det montenegrinske kongerige i 1918 ved et nationaltråd og opløsningen af dennes kirke ved en ekstraordinær synode i 1920. I 1918/20 opgav dermed både staten og kirken sin selvstændighed under pres fra den serbiske hær og pro-serbiske politikere. Staten blev herefter inkorporeret i det nye Slovenske, Kroatiske og Serbiske kongerige, og den tidligere montenegrinske kirke blev en del af den nye fælles ortodokse kirke, der herefter skulle ledes af den serbiske patriark i Beograd. Sekulovićs gennemgang af kilderne til disse begivenheder er ikke kun et historisk studie, men derimod en konkret udformning af et ekklesiologisk argument. Sekulović søger at vise, at det blev en logisk og retslig følge af den montenegrinske stats opløsning i 1918, at den montenegrinske kirke derefter opgav sin selvstændighed. I hans optik var kirkens selvstændighed låst fast på staten i 1918/20, hvorfor det således også bør være en logisk følge, at kirken skal opstå igen med den nye montenegrinske stat efter 2006. De to enheder - stat og kirke - er historisk og juridisk forbundet i Sekulovićs argumentation. Sekulović hævder, at imellem stat og kirke findes et juridisk bånd og en forpligtigelse over for befolkningen. Kirkens forpligtigelse er at sikre, at folket kan dyrke den ortodokse tro på deres sprog, med deres ritualer, liturgi og traditioner i en kirke med folkets navn - med andre ord en montenegrinsk kirke. Sekulović hævder, at den serbiske kirke benægter eksistensen af et særegent montenegrinsk sprog, liturgi og ikke mindst navn, hvorfor det eneste rigtige er at ophøje den montenegrinske kirke til Montenegros eneste sande ortodokse kirke. Udtrykket for den montenegrinske stats absolutte uafhængighed, i Sekulovićs optik, er oprettelsen af en selvstændig autokefal kirke. ${ }^{7}$

Det autokefale (gr. egl. eget-hoved) begreb er den ortodokse kanoniske status, som selvstændige kirker har. ${ }^{8}$ Begrebet stammer fra

5. Kenneth Morrison, Montenegro - A Modern History (London: I.B. Tauris, 2009) $128-132$.

6. Interview af Stevo Vucinic, talsperson for den montenegrinske kirke, d. 10.10.2013, Podgorica. Vucinic omtalte Sekulović som en mand "af god tro" og stod inden for hans argumentation.

7. Goran Sekulović,"Crnogorska identitetska prava i slobode”, Matica Crnogorska 44 (2010), 1-74.

8. Den ortodokse kirke operer endvidere med en status, der kaldes autonom. Denne status giver en kirke ret til at give sine egne "love", liturgi etc. alt imens kirken fortsat er underordnet sin "moderkirkes" patriark. Se evt. Peter Hauptmann, Art. “Orthodox Churches (1.3 Structure.)”, RPP Online (besøgt 11.08.2014). Det er 
en betegnelse som den autoritative byzantinske kanon-kommentator Theodore Balsamon i det tolvte århundrede anvendte i hans kommentarer til de kanoniske tekster. Balsamon udleder begrebet autokefal fra Kanon II fra Konstantinopel i 381. Den autokefale status betegner i Balsamons kommentar først og fremmest en kirkelig uafhængighed, som er relateret til en fri kirkelig administration af et givet område og en lokal synodes ret til selv at ordinere. Betegnelsen er ikke et juridisk princip i hans kommentar, men blot en beskrivelse af den faktiske styreform kirkelige enheder (bispedømmerleparkier) havde, som det er lovfæstet i bl.a. Kanon II. Den autokefale betegnelse vokser ud af en bestemt historisk praksis og blev en status, der dækker over en række kanonisk-juridiske rettigheder såsom retten til egen synode, liturgi og patriark. ${ }^{9}$ Sekulović anvender begrebet i dets senere kanoniske-juridiske betydning.

Sekulovićs ovenfor nævnte historiske og primært juridiske argumentation for den montenegrinske kirke er en udformning af en række konkrete ekklesiologiske definitioner. Han hævder, at den lokale dennesidige ortodokse kirke er sammenfaldende med en stat og et folk, såvel som kirken defineres af dens liturgiske sprog, af den lokalt bestemte udformning af ritualer og ikke mindst af dens navn. Disse ydre udformninger peger alle tilbage på "folket" (serb.: narod) som center, hvorfor den sande ortodokse kirke er et udtryk for et bestemt folks spiritualitet. Denne ekklesiologi er i direkte forlængelse af "den komplette montenegrinske nationale synodes" udmelding den 6. januar 1991, der blev baggrunden for oprettelsen af kirken i 1993. Synoden udtalte, her i Kenneth Morrisons gengivelse og oversættelse:

It is an indisputable fact that the Montenegrin Orthodox Church, for several bloody centuries, was the headquarters of Montenegrin statehood and spirituality, and it is unreasonable and culturally untenable that today, when the Montenegrin people have again won their own

værd at bemærke, at ingen af parterne i Montenegro refererer til denne status i deres argumentation. Denne status er ellers ofte anvendt som et kompromis mellem en "moderkirke" og denne menighed, som eks. Den Økumeniske Kirke og dens datterkirke i Finland, (http://www.ort.fi/en, besøgt 11.08.2014).

9. Se Balsamons kommentar hos The Orthodox Church of Estonia, "Documents of the second ecumenical council A.D. 381", overs. Henry R. Percival, 1899 (http://www.orthodoxa.org/GB/orthodoxy/canonlaw/canons2econcileGB.htm 15.12.2013). Det er værd at være opmærksom på, at Balsamons kommentar er en stærk pro-imperial og økumenisk patriakal kommentar, hvorfor den ofte forsøger at centrere magten til Konstantinopel. Clarence S.J. Gallagher "Theology and Canon Law in the writings of Theodore Balsamon", The Jurist 56 (1996) 161-181. Se evt. Alexander Schmemann, "The Idea of Primacy in Orthodox Ecclesiology”, SVSQ 4 (1960), 49-75. 
national state, the Montenegrin orthodox Church is subordinate to another state's church [den serbiske kirke]. ${ }^{10}$

\section{Spørgsmålet om den autokefale status}

Det centrale kanoniske spørgsmål i kirkestriden er derfor, hvorvidt den montenegrinske kirke er autokefal eller ej. Dette er diskussionens teologisk-dogmatiske kerne, hvorfra forståelsen af den ortodokse ekklesiologi udfoldes.

Spørgsmålet er derfor centralt placeret i Sekulovićs argumentation for den montenegrinske kirke. Sekulović søger gennem sine kildestudier af perioden før 1918 at vise, at den montenegrinske kirke blev opfattet og behandlet som en autokefal kirke. I denne argumentation beskriver han en bestemt historisk fortolkning af den montenegrinske kirkes historie.

I denne fortolkning antager den montenegrinske kirke allerede en autokefal form under vladikaernes (Montenegros bispe-prinser) teokratiske styre fra 1603. Denne status blev formelt anerkendt af den russiske patriark under Vladika Danilo I (1697-1735), idet det montenegrinske territorium - og dermed det kirkelige hierarki - aldrig kom under osmannisk styre og dermed aldrig under den økumeniske patriarks jurisdiktion, der formelt set var den kirkelige leder for de ortodokse kirkesamfund i det osmanniske imperium. Sekulović anfører bl.a. en række korrespondancer mellem kirkeledere og den montenegrinske kirke som bevis for dette. I korrespondancerne tiltales den montenegrinske kirke som en ligestillet partner. ${ }^{11}$

Sekulović historiske studier er ikke enestående, idet en række fremtrædende pro-montenegrinske akademikere har udgivet sammenlignelige historiske studier af den montenegrinske kirkes status. Et af de mere omfattende studier er den montenegrinske historiker Novak Adžićs artikel "Flere beviser for autokefali" (serb.: Nekoliko svjedočanstava o Autokefalnosti), der gennemgår op mod 110 enestående dokumenter fra forskellige statslige montenegrinske arkiver. ${ }^{12}$ Dette omfattende arbejde er et samlet forsøg på at vise, at den montenegrinske kirke var anerkendt som autokefal i det ortodokse kirkefællesskab før 1918. Et eksempel på en af de fremtrædende kilder, som Sekulović argumenterer ud fra, er den montenegrinske kirkes forfat-

10. Morrison (2009) 130.

11. Sekulović (2010), 9-11.

12. Novak Adžić, "Nekoliko svjedočanstava o Autokefalnosti", Crnogroska pravoslavna Crka, Montenet, (http://www.montenegro.org.au/cpcnovak.html, besøgt 15.12.2013). 
ning, som blev vedtaget af dennes synode i 1903, hvor der i artikel 1 . står, at kirken er et:

Autokefal ortodoks metropolitanat i riget Montenegro, som er medlem af den ene, hellige, katolske og apostolske kirke, hvis hyrder og hoved er Gud Jesus Kristus. ${ }^{13}$

Sekulović hævder på baggrund af disse kilder, at den montenegrinske kirke er autokefal, idet den før 1918 havde denne status.

Sekulović pointerer dog også selv en svaghed i hans og andres historiske argumentation for den montenegrinske kirke. Denne svaghed beror på det faktum, at den økumeniske patriark aldrig har udgivet et dekret - en såkaldt tomos - som formelt kirkeretsligt proklamerer kirkens autokefale status, som det eksempelvis skete med den rumænske kirke $1885 .{ }^{14}$ Sekulović hævder, at denne mangel kun skyldes, at den montenegrinske kirke i århundreder havde været autokefal, hvorfor man ikke fandt det nødvendigt at udmelde det åbenlyse. ${ }^{15}$

Sekulovićs udlægning af det autokefale princip bygger primært på historisk-juridiske pointer, men han konstruerer endvidere en distinkt teologisk fortolkning af begrebet. Han hævder, at spørgsmålet om autokefal status slet ikke burde være et problem i den montenegrinske kirkestrid. Den serbiske kirke er slet ikke i en position til at give eller anerkende denne status, da den "ortodokse tradition" foreskriver en helt bestemt udfoldelse af forholdet mellem stat, territorium og kirke. ${ }^{16}$ Sekulović definerer den "ortodokse tradition" (serb.: pravoslavnoj tradiciji) vedrørende spørgsmålet om autokefal status således:

Den ortodokse tradition er den regel, hvor en autokefal kirkes jurisdiktion identificeres med grænserne for en selvstændig nation (nation, stat, kirke).$^{17}$

13. Sekulović (2010), 10, serb.: "Avtokefalna pravoslavna Mitropolija u Knjaževini Crnoj Gori, kao član jedine, svete, katoličanske i apostolske crkve, kojoj je pastironačelnik i glava Gospod i Bog naš Isus Hristos.”

14. Mihai Săsăujan, "The diplomatic negotiations carried out by the Romanian Government with the Ecumenical Patriarchate of Constantinople for the recognition of the autocephaly of the Romanian Orthodox Church (1885)", Östkirchkeliche Studien Band 61 (2012), 245-263.

15. Sekulović (2010), 14.

16. Ibid., 15.

17. Ibid., 15, serb.: "Na sva ova pitanja je već odavno odgovoreno u pravoslavnoj tradiciji i pravilu poistovjećivanja granica nezavisnih državnih i autokefalnih crkvenih jurisdikcija (nacija, država, crkva)”. 
Sekulović hævder, at denne tradition, vedrørende grænsedragning mellem kirkerne og sammenfaldet mellem selvstændige stater og autokefale kirker, stammer fra det fjerde koncils kanoniske beslutninger (Chalkedon 451). Denne regel er udviklet fra den ortodokse tradition om "pentarkiet" (ser.: pentrahije) ${ }^{18}$ der fastslår, at de fem oprindelige "patriarker/ærkebisper" er kirkens øverste autoriteter. Sekulović fremhæver, at denne ortodokse tradition betyder, at det:

at have sin egen autokefale kirke [...] ikke bare [er] en mulighed, men mere en pligt for enhver stat og dets folk. Den ortodokse tradition definerer båndet mellem kirke og stat som organisk og uadskilleligt. ${ }^{19}$

Sekulovićs forståelse af den autokefale status betyder i praksis, at en stat og kirkes grænser er sammenfaldende. Det er et organisk forhold, hvor kirken vokser frem med den selvstændige stat, sàvel som staten vokser frem med den selvstændige kirke. Statens territorium sætter dermed grænser for kirkens organisering. Kirken kan ikke overskride det politiske statslige skel. På den anden side spejler både staten og kirken folket, hvorved de begge bliver konkrete udtryk for folket og dets særegne historie, kultur, sprog med videre. Kirken kan, ligesom staten, kun eksistere i forlængelse af et folks vilje til selvstændighed. Kirken og staten udgår fra folket. De tre enheder danner med Sekulovićs ord: "en hellig montenegrinsk fri treenighed - Montenegros historiske enhed mellem folk, stat og kirke." 20

\section{Sandhedens fort}

Den serbiske ortodokse kirke i Montenegro har i en række artikler, bøger og pressemeddelelser argumenteret imod den montenegrinske kirkes krav på selvstændighed. I det følgende afsnit bliver denne kritik af den montenegrinske kirke og dens ekklesiologi gennemgået. Analysen vil primært tage udgangspunkt i skriftlige kilder fra den serbiske kirke indsamlet i Montenegro i oktober 2013.

18. Det kirkeretslige navn for de fem ledende bispeføderationer - kendt som de fem patriarkater Jerusalem, Antioch, Alexandria, Konstantinopel og Rom. Rom tælles som regel med i opregning af de "fem sæder", hvorefter der ligeså regelmæssigt kommenteres, at Rom mistede sin ret efter ekskommunikationen i 1054.

19. Sekulović (2010), 15, serb.: "usvojeno je da svaka država i narod ne samo da mogu nego i moraju imati sopstvenu, samostalnu crkvu. U pravoslavlju su država i crkva posebito bile organski spupčene, u stvari, neodrješive."

20. Ibid., 6, serb.: "sveto trojstvo slobodne Crne Gore - istorijsko jedinstvo crnogorskog naroda, njegove države i crkve." 


\section{Et spørgsmål om ekklesiologiens udgangspunkt}

Metropolitten Radović har behandlet den montenegrinske kirkes krav på selvstændighed, autokefal status, i en teologisk traktat med titlen "Kirken som søjlerne og fortet for sandhed" (udateret). Denne tekst er en dogmatisk polemisk traktat, der indeholder en behandling af det ekklesiologiske hovedproblem i striden set fra den serbiske kirkes side.

Radović indleder sin tekst med at pointere, at den autokefale status kun er et "ydre" tidsligt fænomen for kirken. Dette ydre er kun en af mange manifestationer for kirkens indre sande væsen, som er Kristus, der er kirkens eneste sande og evige "hoved". Spørgsmålet om autokefalitet skal dermed ses i forlængelse af kristologien, hvis det skal forstås rigtigt. ${ }^{21}$

Radović hævder, at det er ud fra det kristologiske center, at kirken danner en evig og uforanderlig orden. Denne orden determinerer, hvordan frelsen åbenbares, bevidnes og gives. Den sande kirke består derfor først og fremmest af de døbtes fællesskab, der modtager kirkens mysterium og frelse i form af den apostolske tros indhold og som samles $i$ et døbt fællesskab om nadveren under opsyn af presbyterne og biskopperne, der opfylder kriteriet om den apostolske succession. Dette døbte fællesskab kan kun opleves indefra og kan ikke eksistere uden sit center i form af kristologien. Enhver ydre beskrivelse af kirken er tom, hvis den ikke samtidig indeholder den rette (ortodokse) levende tros praksis. ${ }^{22}$

Radović pointerer dermed en række centrale kriterier for, hvad der konstituerer den "sande" kirke. Det primære kriterium er, at kirkens hoved er Kristus og ikke en synode eller patriark. Radović gør den apostolske kristologiske bekendelse til hovedaksen i ekklesiologien, forstået således, at den sande kirke bekender den sande Kristus og er indviet i det kristologiske mysterium i nadveren. Ud fra dette kriterium følger det næste punkt i Radovićs ekklesiologi, nemlig at kristologien er en evig og uforanderlig orden, der åbenbares, bevidnes og gives i kirken. Dåben gøres til et hovedkriterium for at mennesket kan få del i det kristologiske mysterium, fordi vedkommende på denne måde kan blive en del af den evige sande kirke. Denne deltagelse i mysteriet foregår ved at deltage i nadveren, som er det ultimative udtryk for det kristologiske center i kirken. Kirkens center

21. Amfilohije Radović, "The Church as the Pillar and Stronghold of the Truth - The Question of Autocephality and the Church", Orthodox Research Institute (http://www.orthodoxresearchinstitute.org /articles/canon_law/ amfilohije_radovic_church_pillar.htm, besøgt 19.12.2013).

22. Ibid. 
er nadveren, hvor de døbte optages i det evige og uforanderlige sande kirkefællesskab. Radovićs ekklesiologi centrerer sig om eukaristien. Eukaristien er den reelle oplevelse, som de troende får, hvorfor den er kirkens primære praksis og indgangen til det kirkelige fællesskab. Ekklesiologien antager dermed en sakramental form som sit primære udtryk.

Dette sakramentale udtryk er ikke blot underlagt kriteriet om den sande kristologiske bekendelse og deltagernes dåb, men er endvidere underlagt kravet om det rette opsyn. Det vil sige, at sakramentet kun er gældende og sandt, såfremt det foregår under opsyn af presbyterer eller biskoppen, der lever op til kriteriet om den apostolske succession. Det er altså kun under opsyn fra en bispeviet person, der er retmæssig efterfølger af den apostolske tolvkreds, at sakramentet kan siges at være sandt.

Dette indre fællesskab i den sande kirke kan, ifølge Radović, ikke forveksles med kirkens ydre fremtoning i form af bygninger eller nationalt fællesskab. En dyrkelse af de ydre fremtoninger frem for det rette eukaristi er idol-dyrkelse. Det er dyrkelse af menneskets selvskabte idoler, hvorfor det naturligvis, for Radović, er afgudsdyrkelse og kætteri. Over for de menneskelige "sekter" og "såkaldte kirker" underforstået den montenegrinske - står den sande ortodokse kirke, der kendetegnes ved, at "Hun" har:

kept Her faithfulness [...] confirming this loyalty and testing it against the apostolic succession of the living Tradition of genuine truthfulness and genuine Church constitution (ibid.).

Radović hævder på den baggrund, at kirken kan forstås som eet subjekt, der er kendetegnet ved at leve i overensstemmelse med den genuine og sande tradition (den patristiske) og konstitution (de kanoniske lovsamlinger). Kirken er dermed kendetegnet ved at følge de to primære ortodokse traditioner i form af kirkefædrenes overleveringer og de kanoniske bekendelser og beslutninger. Den sande kirke kan kun eksistere ud fra sin loyalitet til de apostolske sæder i pentarkiet (ibid.). Det er pentarkiet, der dannede kanon, som enhver ny kirke uanset navn - er bundet op på. Radović pointerer, at:

All these titles are historically conditioned and they have been used to express an inner truth of The Church, Her universal message and meaning and not vice versa. The criteria of The Church and ecclesiality, the essential and everlasting in Her, have never been nor today are her "garments" and titles and names acquired through history [...] the only essential quality of the Church that orthodox Christians confess at 
every Divine Liturgy is: "I believe in one, holy, catholic, and apostolic Church" (ibid).

Den autokefale titel er ikke et tegn på en sand kirke, men kun et historisk ydre tegn der uden relationen til den sande ortodokse tradition er værdiløs. Det essentielle tegn i ekklesiologien er den bekendende natur i liturgien, hvis højdepunkt er eukaristien, hvor den døbte forsamling bekender sig til den ene, hellige, "katolske" og apostolske kirke i overensstemmelse med det apostolske (nicænske) symbol. ${ }^{23} \mathrm{En}$ sand kirke skal altså være i overensstemmelse med apostolske symbols definition - uden at Radović udtømmende definerer de fire kriterier (en, hellig, katolsk og apostolsk).

I liturgien udsiges kirkens kerne. Såfremt man fremhæver en nations eller et folks navn på dette sted i liturgien, så gør man sig, ifølge Radović, skyldig i kætteri. Radović fremhæver, at:

Behind this temptation lies the idea of the deification of the nation and the transformation of the living God into a tribal deity together with placing the Church in the position to cater for the lowly, political interests. ${ }^{24}$

Når man fremhæver nation og folk forud for kirkens sande kerne, så er det en reducering af Gud og en idol-dyrkelse af nationen, hvorfor den montenegrinske kirke er skyldig i en række brud med den ekklesiologi, som Radović plæderer for. Den montenegrinske kirke er, for Radović, et forsøg på at misbruge kirken og Gud i en politisk sags tjeneste. I Radovićs optik er hans modstandere i den montenegrinske kirke dermed både skyldige $\mathrm{i}$ et skisma, et kætteri og en idol-dyrkelse af en "nation" og af titlen autokefal. ${ }^{25}$ Det er værd her at nævne, at talrige forskere og iagttagere har kritiseret den serbiske

23. De ortodokse kirker kalder det symbol, som i vestkirken er kendt som det nicænske, for det apostolske. Det er endvidere værd at være opmærksom på, at ordet "katolsk" har en væsentlig anden betydning i ortodoks sammenhæng end i den reformatoriske, protestantiske eller katolske udgave. Se eks. Georges Florovsky, , "The Catholicty of the Church", Bible, Church, Tradition: An Eastern orthodox view, Collected Works of Georges Florovsky, vol. 1, (Vaduz: Büchervertriebsanstalt,1987)

24. Radović, udateret

25. Radović ligestiller derfor den montenegrinske kirkes kætteri med fyletisme, hvilket er navnet på det nationalistisk kætteri, der blev fordømt i af en lokal synode i 1872 i Konstantinopel. Se evt. Riis (1999) 231-236 og Stephane Bigham, " The 1872 Council of Constantinople and Phyletism” ( http://ocl.org/the-1872-councilof-constantinople-and-phyletism/, besøgt 10.09.2013) 
kirke for netop selv at bruge kirken i politisk og nationalt øjemed i eks. Montenegro. ${ }^{26}$

I forlængelse af den ovenstående argumentation hævder den serbiske kirke, at den montenegrinske kirke kun deler nadverfællesskab med det "skismatiske" ukrainske Kiev-patriarkat, der er i et åbent opgør med den russiske kirke, Moskva-patriarkatet. I modsætning hertil fremviser den serbiske kirke eksempelvis, at de ved åbningen af den nye katedral i Podgorica den 7. oktober 2013 delte nadver med den russiske, økumeniske og den ortodokse kirke i Jerusalem. Den serbiske kirke fremhæver dermed sit nadverfællesskab med de andre ortodokse kirker, som et tydeligt tegn på deres sande ortodokse lære. ${ }^{27}$

\section{To ekklesiologiske modeller}

Sekulović og Radovićs fremskriver på hver deres måde markante ekklesiologiske positioner, der i høj grad er præget af den eksisterende konflikt og hvis argumenter er tilpasset denne samtidige kontekst. I deres ekklesiologiske positioner kommer der en åbenlys spænding $\mathrm{i}$ den moderne ortodokse ekklesiologi til syne, som i det følgende vil blive diskuteret.

\section{Den eusebiske ekklesiologi}

Sekulović hævder, at en selvstændig (autokefal) kirkes grænser følger de verdslige staters grænser, og at en autokefal kirke er en kirkeretslig konsekvens af oprettelsen af en ny stat. Han hævder, at dette er den særlige "ortodokse tradition", der stammer fra koncilet i Chalkedon i 451. Han forstår dermed den autokefale status som konsekvens af de kanoniske beslutninger fra Chalkedon, hvilket i denne sammenhæng må forstås som Kanon XVII fra 451, der konkret omtaler oprettelsen af nye kirkeenheder ved oprettelsen af nye byer/stater. Sekulović forsøger at gøre denne Kanon til den kanoniske-juridiske baggrund for hans argumentation. Men Kanon XVII, som den ordret optræder i den kanoniske samling, omtaler dog kun byer, der oprettes efter "imperialt dekret". ${ }^{28}$ Endvidere refererer Kanon XVII til to centrale

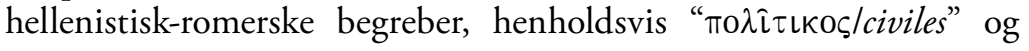

26. Se eks. Šistek (2010).

27. Interview af diakon Igor Belaban, Cetinje klosteret, d. 15.10.2013.

28. Decrees of the Ecumenical Councils, ed. Norman P. Tanner S.J., vol. I, (London \& Washingtin DC: Sheed \&Ward and Georgtown University Press, 1990), 9. 


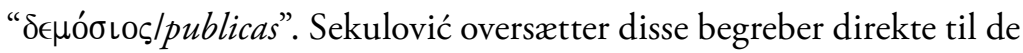
montenegrinske ord narod (folk) og država (stat), hvilket kun kan gøres med en række væsentlige semantiske forbehold. Hans fortolkning af Kanon XVII ignorerer de historiske forhold, såsom eksistensen af en kejserlig autoritet og den hellenistiske-romerske stats og by opfattelse. Disse forhold udelader han fuldkomment i sin fortolkning. På sammen måde forholder det sig med de sproglige aspekter af denne kanon, hvor hans fortolkning virker som en bevidst fordrejning af det kanoniske materiales semantik. ${ }^{29}$

Sekulović overser de ovenstående forhold i den kanoniske lovsamling og dens kontekst, men hans fortolkning har stadig en vis historisk relevans. I den ortodokse kirkeret findes der ganske vist ingen specifik "ortodokse tradition" på området, men den kanoniske lovsamling er de facto og de jure blevet anvendt i det nittende og tyvende århundrede, som Sekulović anfører. Hans forståelse af den autokefale status og fortolkningen af Kanon XVII flugter faktisk med den ortodokse praksis. Sekulovićs ekklesiologi, hvor et selvstændigt folk skal have en selvstændig autokefal kirke, er en model, der i udpræget grad beskriver den historiske udvikling i de slaviske ortodokse kirker og nationalistiske bevægelser i det syttende og attende århundrede. Denne udvikling ses eksempelvis i den økumeniske patriark Joakim den III's brev fra 1879, der tildelte den serbiske kirke autokefal status på ny, efter stormagternes anerkendelse af den nye serbiske stat året før. ${ }^{30}$ I brevet fremhæver Joakim III ligefrem, at nye politiske situationer og formationen af en ny politisk enhed i sig selv var grund til, at den serbiske kirke kunne få tildelt autokefal status. ${ }^{31}$ Den samme praksis kan ses i de diplomatiske forhandlinger om den rumænske kirkes autokefale status i 1885 mellem den rumænske regering og den økumeniske patriark. ${ }^{32}$

Sekulovićs ekklesiologi stemmer dermed faktuelt overens med det, som Andrew Louth karakteriserer som "eusebisk" ekklesiologi, der dækker over den distinkte ortodokse historiske nationale kirkelige model. ${ }^{33}$ Den ekklesiologiske model forudsætter en tæt sammenhæng

29. Ibid.

30. Kirkens status som autokefal var I ophævet fra 1766 , som sultanatets respons på en række serbiske oprør ledt af bl.a. Den serbiske patriark. Kirken fik sin autokefale status tilbage efter den serbiske stat blev anerkendt som selvstændig efter konferencen i Berlin i 1878.

31. Alexander Bogolepov, "Conditions of Autocephaly (I)". SVSQ 5 (1961), 11-37 (17-18).

32. Săsăujan (2012).

33. Modellen er opkaldt efter kirkehistorikeren Eusebius, idet modellen udvikles ud fra samlingen af gejstlig og sekulær magt i det østromerske rige, som sker efter Konstantin d. store og har et af sine første udtryk i Eusebius skrifter. Dette kaldes 
mellem verdslig og gejstlig magt, hvor begge institutioner fungerer i det som ortodokse teologer og byzantinsk kirkeret kalder for et symfonisk forhold. Den eusebiske model er en videreudvikling af den byzantinske teokratiske statsmodel, som de slaviske kirker overtog og som blev genbrugt i de nationale bevægelser, hvor kirken og "folket" blev knyttet sammen. Kirkelig selvstændighed var simpelthen forudsætning eller direkte følge af et folks statslige selvstændighed. ${ }^{34}$ John Meyendorff fremhæver, at en autokefal status blev anset af de nationale bevægelser i Østeuropa som en kirkelig variant til et folks nationale selvstændighed. National selvstændighed medførte autokefal status for den lokale kirke, såvel som en autokefal kirke var garant for en national selvstændighed. ${ }^{35}$

Denne ekklesiologiske model er, på trods af dens historisk set anakronistiske indhold, i høj grad baseret på de ortodokse kanoniske forskrifter. ${ }^{36}$ Sekulovićs ekklesiologi, der argumenterer for den montenegrinske kirkes autokefale status, er et moderne eksempel på denne eusebiske model.

Samlende må man sige, at den montenegrinske kirkes krav og argumentation for autokefal status ikke blot er et udtryk for, at de ønsker kirkelig selvstændighed. Sekulovićs krav om autokefal status og argumentationen herfor er en forlængelse af den historiske eusebiske ekklesiologiske model. Dette er en særlig ortodoks ekklesiologisk model, der følger en bestemt historisk udvikling i de slaviske kirker, som nærmere er beskrevet af Louth. ${ }^{37}$

\section{Ekklesiologisk nyorientering}

Radović og den serbiske kirkes kritik af den moderne montenegrinske kirkes position er i sammenligning med Sekulovićs ekklesiologi mere teologisk betydningsfuld. Centralt i Radovićs argumentation er det apostolske (nicænske) symbol, hvis ekklesiologiske grundpræmisser er eukaristien og dets kristologiske og pneumatologiske implikationer.

ofte - og jf. moderne byzantinske og ortodokse studier helt fejlagtigt - for "casaropapisme". Se Andrew Louth, "Ignatios or Eusebius: two models of patristic ecclesiology", International journal for the Study of the Christian Church 10 (2010), 47-49.

34. Daniela Kalkandjieva, "A Comparative Analysis on Church-State Relations in Eastern Orthodoxy: Concepts, Models, and Principles", JChSt 53, 4 (2011), 587614 (592, 598-99).

35. John Meyendorff, The Byzantine Legacy in the Orthodox Church, (Crestwood, NY: St. Vladimir's Seminary Press, 1982), 227.

36. Louth, (2010), $47 \mathrm{f}$.

37. Ibid. 
Radović foretager det, som kan karakteriseres som en neo-patristisk syntese. I hans argumentation vender Radović tilbage til en "patristisk" kilde, i form af det apostolske symbol, som han anvender til at give svar på et moderne spørgsmål, nemlig spørgsmålet om den autokefale status' relevans i en moderne kontekst. Denne teologiske argumentationsform er udviklet af de fremtrædende ortodokse diaspora-teologer Georges Florovsky (1893-1979) og Nikolas Afanasiev (1893-1966). Florovsky og Afanasiev er kendt som grundlæggerne af den ortodokse "neo-patristiske" skole og den eukaristiske ekklesiologi. ${ }^{38}$ Skolen er kendetegnet ved, at dens teologi søger tilbage til kirkefædrene $i$ et forsøg på at formulere en moderne teologi. Denne praksis definerer Florovsky selv således:

It must be a synthesis, a creative reassessment of those insights which were granted to Holy Men of old. It must be Patristic, faithful to the spirit and vision of the Fathers, ad mentem Patrum. Yet it must also be Neo-Patristic, since it is to be addresses to the new age, with its own problems and queries. ${ }^{39}$

Radović anvender den neo-patristiske logik på det apostolske symbol, hvormed han fremhæver symbolets forrang, som det får ved at være en patristiske kilde, der besidder en højere grad af pneumatologiske forrang forud for senere kirkelovgivning. Den ydre omstændighed er, ifølge Radović, irrelevant, såfremt den ikke stemmer overens med pneumatologien eller kristologien i symbolet. Det er altså det rette eukaristi og ikke kirkelovgivningen, der gør forsamlingen til en del af Kristi sande legeme.

Radovićs teologiske udgangspunkt i hans tekst flugter dermed med hovedpointerne i den neo-patristiske skoles eukaristiske ekklesiologi, som Andrew Louth karakteriserer som Ignatiske. ${ }^{40}$ Denne ekklesiologi er i høj grad udviklet af Florovsky og Afanasiev samt deres elev John Zizioulas, der enstemmigt hævder, at kirkens bærende form findes i de lokale ortodokse kirker, der er konstitueret omkring et eukaristi. En anden af Florovskys elever, John Meyendorff, konkluderer ligefrem i sit hovedværk Byzantine Theology, at kirkens primære form netop var konstitueret ud fra nadveren, som forblev "the ulti-

38. Kallistos Ware, "Sobornost and eucharistic ecclesiology:Aleksei Khomiakov and his successors", International journal for the Study of the Christian Church 11 (2011), 216-235 (218).

39. Kallistos Ware, "Orthodox theology today: trends and tasks", International journal for the Study of the Christian Church 12 (2012), 105-121 (109-111).

40. Ekklesiologien kaldes Ignatisk, idet den udledes fra et citat fra kirkefaderen Ignatious. Se Louth (2010), 51. 
mate theological norm for ecclesiastical structure". ${ }^{41}$ Nadverens kristologiske og pneumatologiske implikationer konstituerer en enhed, der transcenderer den enkelte menigheds afsondrethed ind i en fælles ortodoks katolsk forsamling med de andre ortodokse kirker. ${ }^{42}$

Radovićs anvender dette udgangspunk til at kritisere den montenegrinske "eusebiske" ekklesiologi. Radovićs udgangspunkt muliggør, at de kirkeretslige og byzantinske kilder kan negligeres til fordel for de apostolske. De kirkeretslige regler og den afledte ekklesiologi anses som sekundær i forhold til de apostolske kilders ekklesiologi. Det er vigtigere, hvordan kirkefædrene beskriver kirken end, hvordan kirken defineres i de senere ortodokse kanoniske love. Det vil sige, at de eusebiske ekklesiologiske grundantagelser, som stammer fra det kanoniske materiale, kan afvises med udgangspunkt i neo-patristisk ekklesiologi, idet andre antagelser gives en pneumatologisk betinget forrang.

Denne logik ses tydeligt i Radovićs kritik af den montenegrinske kirke. Han afviser det kirkeretslige og de kanoniske argumenter som en ydre historisk præmis og anvender i modsætning hertil eukaristien og pneumatologien som ekklesiologiske grundpræmisser. De legalistiske præmisser for kirken, såsom indholdet af Kanon XVII fra Chalkedon, er dermed negligeret til fordel for en apostolsk definition af kirken. Radović hævder i forlængelse af denne argumentation, at hans modstandere er kættere, idet de dyrker de historiske præmisser, folket og den autokefale status, frem for kirkens sande center, eukaristien. Denne argumentation kan ved brugen af den pneumatologiske præmis negligere de historiske og kirkeretslige argumenter, som Sekulović anvender. Radović behøver dermed slet ikke argumentere kirkeretsligt eller historisk-teologisk, idet han kan reducere Sekulovićs argumenter til udelukkende at være ydre omstændigheder, der ikke vedrører kirkens sande væsen. Sekulović argumentation og ekklesiologi gøres dermed uvæsentlig i neo-patristisk teologisk forstand.

Den montenegrinske kirkes historisk givne skismatiske position, der dybest set beror på en manglende anerkendelse fra de andre or-

41. John Meyendorff, Byzantine Theology - Historical Trends and Doctrinal Themes, (New York: Fordham University Press 1974), 209.

42. Se Georges Florysky, "The Church: Her Nature and task", Bible, Church, Tradition: An Eastern orthodox view, Collected Works of Georges Florovsky vol. 1, (Vaduz: Büchervertriebsanstalt 1987), 57-72 (59) og Georges Florovsky, "The Catholicty of the Church", Florovsky (1987), 37-56 (40); John Zizoulas,"The Eucharistisc Community and the Catholicity of the Church", The New Man - an Orthodox and Reformed Dialogue, red. John Meyendorff \& Joseph McLelland (New Brunswick: Agora Books 1973), 107-131. Se endvidere Veli-Matti Kärkkäinen, An introduction to Ecclesiology (Downers Grove: InterVarsity Press, 2010), 17-26 samt 95-103 for en uddybning og kommentering til Florovsky og Zizoulas ekklesiologi. 
todokse kirker, anvendes hermed som udgangspunkt for en pneumatologisk betinget kritik. Den montenegrinske kirkes manglende nadverfællesskab med de andre patriarkater udgør et pneumatologisk argument imod dem. En kirke uden det rette nadverfællesskab lever ikke op til den apostolske definition af kirken i den neo-patristiske ekklesiologi, hvorfor kirkens eksistens strider mod den apostolske trosbekendelse.

\section{To teologiske ekklesiologiske hovedmodeller}

På baggrund af analysen og diskussionen er det tydeligt, at de to kirkers positioner forenklet kan karakteriseres teologisk som udtryk for to forskellige ekklesiologiske modeller. På denne ene side findes den montenegrinske kirke, der primært opererer med den legalistiskehistoriske eusebiske model og dennes anvendelse af kanoniske regler. På den anden side findes den serbiske kirke, hvis position kan karakteriseres som en neo-patristisk ekklesiologi.

Den montenegrinske kirke opererer med andre ord med en byzantinsk model, der er blevet nationaliseret, og som i udpræget grad anvender den kanoniske lovsamling. Denne positions argumentation er opbygget af kanoniske regler, men der trækkes på en distinkt ortodoks fortolkning af disse regler fra det nittende og tyvende århundrede. Hovedelementet i denne ekklesiologi er kravet om autokefal status, som opfattes som ækvivalent til national selvstændighed. Den eusebiske model er ganske anvendelig for nationalistiske bevægelser, idet den underbygger et krav om kirkelig selvstændighed som forlængelse af politisk selvstændighed. Modellen underbygger forholdet mellem "folk" og kirke.

Den serbiske kirke opererer i modsætning til den montenegrinske med en ekklesiologi, der trækker på den neo-patristiske skole. Centralt for denne model er nadveren og nadverfælleskabet med de andre ortodokse kirker, som konstituerer det primære kriterium for, at en kirke er en sand ortodoks kirke. Denne model afviser den kanoniske samling som øverste autoritet i kirkelige sammenhænge, idet de patristiske kilder tillægges en højere pneumatologisk værdi. Denne ekklesiologi, med dens fokus på det samlende ortodokse fællesskab, er en teologi, der tenderer til at favorisere de allerede etablerede kirker i forhold til nye kirker, der ofte - som i Montenegro - vil stå i et historisk givet skismatisk forhold til de kirker, som de har ladet sig udskille fra.

De to modeller er i særlig grad fokuseret på to af de mest centrale sider i ortodoks ekklesiologi. På den ene sider er den eusebiske model 
opbygget omkring de kanoniske lovsamlinger, alt imens den neopatristiske model i højere grad fokuserer på den patristiske tradition. Forskellen i de to modeller er, at de fokuserer på hver deres hovedområde i den ortodoks ekklesiologi. Et fokus der udnytter den ortodokse ekklesiologis indre spændinger, mellem moderne neo-patristisk teologi, byzantinsk kirkret og historiske samt nationale forskydninger i Østeuropa, til at opbygge ekklesiologiske positioner i sammenstødet med lokale kirkelige modstandere. 